\title{
Cloning and Characterization of RGS9-2: A Striatal-Enriched Alternatively Spliced Product of the RGS9 Gene
}

\author{
Z. Rahman, ${ }^{1,2}$ S. J. Gold, ${ }^{2}$ M. N. Potenza, ${ }^{2}$ C. W. Cowan, ${ }^{3,4}$ Y. G. Ni, ${ }^{2}$ W. He, ${ }^{4}$ T. G. Wensel, ${ }^{3,4}$ and E. J. Nestler ${ }^{2}$ \\ ${ }^{1}$ Department of Molecular, Cellular and Developmental Biology, ${ }^{2}$ Laboratory of Molecular Psychiatry, Yale University, New \\ Haven, Connecticut 06508, and ${ }^{3}$ Program in Cell and Molecular Biology, ${ }^{4}$ Verna and Marrs McLean Department of \\ Biochemistry, Baylor College of Medicine, Houston, Texas 77030
}

Regulators of G-protein signaling (RGS) proteins act as GTPase-activating proteins (GAPs) for $\alpha$ subunits of heterotrimeric G-proteins. Previous in situ hybridization analysis of $\mathrm{mR}$ NAs encoding RGS3-RGS11 revealed region-specific expression patterns in rat brain. RGS9 showed a particularly striking pattern of almost exclusive enrichment in striatum. In a parallel study, RGS9 cDNA, here referred to as RGS9-1, was cloned from retinal cDNA libraries, and the encoded protein was identified as a GAP for transducin $\left(\mathrm{G} \alpha_{\mathrm{t}}\right)$ in rod outer segments. In the present study we identify a novel splice variant of RGS9, RGS9-2, cloned from a mouse forebrain cDNA library, which encodes a striatal-specific isoform of the protein. RGS9-2 is 191 amino acids longer than the retinal isoform, has a unique $3^{\prime}$ untranslated region, and is highly enriched in striatum, with much lower levels seen in other brain regions and no expres- sion detectable in retina. Immunohistochemistry showed that RGS9-2 protein is restricted to striatal neuropil and absent in striatal terminal fields. The functional activity of RGS9-2 is supported by the finding that it, but not RGS9-1, dampens the $\mathrm{G}_{\mathrm{i} / \mathrm{o}}$-coupled $\mu$-opioid receptor response in vitro. Characterization of a bacterial artificial chromosome genomic clone of $\sim 200$ $\mathrm{kb}$ indicates that these isoforms represent alternatively spliced mRNAs from a single gene and that the RGS domain, conserved among all known RGS members, is encoded over three distinct exons. The distinct C-terminal domains of RGS9-2 and RGS9-1 presumably contribute to unique regulatory properties in the neural and retinal cells in which these proteins are selectively expressed.

Key words: striatum; transducin; alternative splicing; $\mu$-opioid receptor; GTPase-activating proteins; retina
The regulators of G-protein signaling (RGS) proteins constitute a large family of proteins that have been shown to potently modulate the functioning of heterotrimeric G-proteins by stimulating the GTPase activity of G-protein $\alpha$ subunits (for review, see Dohlman and Thorner, 1997; Berman and Gilman, 1998; Zerangue and Jan, 1998). These proteins contain a conserved domain of 120 amino acids referred to as the RGS domain (Koelle and Horvitz, 1996). To date, 20 mammalian gene products containing the core RGS domain have been identified.

RGS proteins negatively regulate signaling via heterotrimeric G-proteins by accelerating the conversion of the active, GTPbound G-protein $\alpha$ subunit to the inactive, GDP-bound conformation (Berman and Gilman, 1998). RGS proteins have been shown to negatively modulate G-protein-coupled neurotransmitter responses in neurons (Saugstad et al., 1998). Investigations of signaling mechanisms in phototransduction (for review, see Arshavsky and Pugh, 1998) and of $\mathrm{K}^{+}$channel activation (Saitoh et al., 1997) suggest that members of the RGS protein family also function as potent regulators of signaling kinetics (Zerangue and

\footnotetext{
Received Sept. 8, 1998; revised Dec. 30, 1998; accepted Jan. 7, 1999.

This work was supported by National Institutes of Health Grants P01 DA08227, T32 MH14276, T32 DA07290, T32 EY907001, RO1 EY07981, and RO1 EY11900, by the Abraham Ribicoff Research Facilities of the Connecticut Mental Health Center, State of Connecticut Department of Mental Health and Addiction Services, and by the Welch Foundation. We thank Drs. Marina Piccioto, Henrik Dohlman, Michael Koelle, and Michael R. Lerner for helpful discussions, Dr. Krzysztof Palczewski for the RGS9 monoclonal antibody, Dr. Colin Barnstable for rat retinas, and Alison Roby-Shemkovitz and Yevette Clancy for excellent technical support. Z.R. and S.J.G. contributed equally to this study.

Correspondence should be addressed to Dr. Eric J. Nestler, Department of Psychiatry, Yale University, 34 Park Street, New Haven, CT 06508.

Copyright (C) 1999 Society for Neuroscience $\quad 0270-6474 / 99 / 192016-11 \$ 05.00 / 0$
}

Jan, 1998). Although the numbers of distinct mammalian RGS proteins and G-protein $\alpha$ subunits are roughly equivalent, it is not well understood how specificity is achieved in their interactions. One likely basis for specificity could be the specific expression patterns of individual RGS members. Striking region-specific expression of RGS proteins in rat brain has been demonstrated (Gold et al., 1997; Shuey et al., 1998). The expression pattern for one RGS family member, RGS9, was particularly interesting: RGS9 mRNA was found to be highly enriched in striatal regions, including caudoputamen, nucleus accumbens, and olfactory tubercle, with very low levels of expression seen throughout the rest of brain. The striatal-enriched expression of RGS9 suggested that it could serve specialized functions as a GTPase-activating protein (GAP) for striatal neurons. A recent report that striatal expression of RGS9 mRNA is downregulated by acute exposure to the psychostimulant amphetamine (Burchett et al., 1998) supports an important role for RGS9 in striatal neurons. In a parallel study, RGS9 cDNA was cloned from murine and bovine retinal cDNA libraries, its mRNA and protein were shown to be expressed only in photoreceptor cells within the retina, and RGS9 was identified as the GAP for the visual G-protein transducin $\left(\mathrm{G} \alpha_{\mathrm{t}}\right)$ (Cowan et al., 1998; He et al., 1998). Because the G-protein and the effector (cGMP phosphodiesterase, PDE VI) with which RGS9 interacts in photoreceptor cells have not been reported to be present in striatum, these studies raised interesting questions about the role of the RGS9 gene and its protein products in these distinct cell types.

The present study was undertaken to examine these questions and characterize striatal RGS9 further at the molecular level. We report here the identification of a full-length cDNA for RGS9, 
which encodes a protein distinct from that encoded by the RGS9 cDNA isolated previously from retina and accounts for its striatal-enriched expression pattern. Sequence comparisons of the two cDNAs, along with the characterization of a $200 \mathrm{~kb}$ bacterial artificial chromosome (BAC) clone corresponding to the RGS9 gene, show that the two forms of RGS9 are splice variants of a single gene. Tissue-specific and reciprocal expression of each form of RGS9 suggests a differential function of the two proteins.

\section{MATERIALS AND METHODS}

Screening of $c D N A$ libraries. A mouse forebrain cDNA phagemid library (Uni-Zap XR cDNA library; Stratagene, La Jolla, CA) made from the C57 mouse strain was screened at a density of 5,000-10,000 plaques/150 $\mathrm{mm}$ Petri dish. Plaques were transferred onto nylon membranes (Hybond-N, Amersham, Arlington Heights, IL); membranes were treated under denaturing conditions and neutralized using standard procedures (Sambrook et al., 1989). Positive cDNA clones were isolated by plaque hybridization using the RGS domain for RGS9 as a radiolabeled probe (kindly provided by M. Koelle, Yale University). Probes were labeled by the random priming method (Boehringer Mannheim, Indianapolis, IN). Hybridization buffer was composed of $5 \times$ SSC $[1 \times$ $\mathrm{SSC}$ (sodium citrate buffer) $=0.15 \mathrm{M} \mathrm{NaCl}$ and $15 \mathrm{~mm}$ sodium citrate, $\mathrm{pH}$ 7.0 ], $5 \times$ Denhardt's solution, and $0.5 \%(\mathrm{w} / \mathrm{v})$ SDS. Hybridizations were performed at $65^{\circ} \mathrm{C}$ overnight, and high-stringency washes were performed using $0.1 \times \mathrm{SSC}, 0.1 \%$ SDS at $65^{\circ} \mathrm{C}$. Positive clones isolated from the cDNA library were subcloned into the pBluescript phagemid with the use of the ExAssist helper phage (Stratagene).

Screening of BAC genomic library and characterization of BAC clones. Screening of a murine genomic library (strain 129 SVJ), constructed using the pBeloBAC11 vector, was performed at Genome Systems (St. Louis, MO). A BAC genomic clone that hybridized to the RGS domain of RGS9 was identified and isolated for further analysis. Plasmid DNA was prepared using the Qiagen plasmid DNA purification systems (Qiagen, Chatsworth, CA). BAC DNA was prepared using the KB-100 magnum purification column (Genome Systems).

Genomic DNA contained in the BAC was "shotgun-subcloned" into the pZero vector (Zero Background PLUS Cloning kit, Invitrogen, Carlsbad, CA) using the manufacturer's recommendations. Briefly, genomic DNA was digested using a six-cutter restriction endonuclease, the cohesive-ended fragments were ligated into the pZero plasmid, the ligation products were transformed into competent cells (One shot TOP10, Invitrogen), and the recombinant clones were selected by use of appropriate antibiotic media. The subcloned colonies were screened by colony hybridization using the novel cloned RGS9 cDNA (see above) as a probe to isolate genomic fragments corresponding to the cDNA sequence. The DNA from lysed bacteria was transferred onto nylon membrane filters (Hybond-N, Amersham) and cross-linked using a UV cross-linker (UVStratalinker 1800, Stratagene) according to the manufacturer's protocol. Hybridization procedures were performed as outlined above.

For BAC Southern blot hybridizations, DNA from the BAC was digested with restriction endonucleases, and $2 \mu \mathrm{g}$ of digested BAC DNA was separated on a $1 \%$ agarose gel, transferred to a nylon membrane (Hybond-N, Amersham), and immobilized by UV cross-linking. Hybridization was performed at $65^{\circ} \mathrm{C}$ as outlined above.

DNA sequencing (primer walking, transposon tagging). Bidirectional nucleotide sequencing was performed using fluorescent dideoxynucleotide sequencing and automated detection (Keck DNA sequencing facility, Yale University, and Pfizer Inc. Central Research Division, Groton, $\mathrm{CT})$. Oligonucleotides used for the primer-walking were synthesized at the Keck Oligonucleotide Synthesis Facility (Yale University). Nucleotide and protein sequences were aligned using the MacVector and/or Lasergene software. Sequence analysis and homology searches were performed using the profile scan and prosite tools at the ISREC server (http://www.isrec.isb-sib.ch/).

Transposon tagging using the Primer Island Transposition Kit (PE Applied Biosystems, Foster City, CA) was performed with the genomic fragments subcloned into $\mathrm{pZ}$ ero. This in vitro transposition system places unique primer binding sites randomly in a population of large DNA molecules. These primer sites were subsequently used for DNA sequencing reactions, making it possible to simultaneously sequence large regions of DNA. Transposon insertion, an alternative to subcloning or primer walking when sequencing a large region of DNA, was performed essen- tially as described elsewhere (Devine and Boeke, 1994). Briefly, transposons were randomly integrated into the target DNA in an in vitro transposition reaction; the DNA was isopropanol-precipitated and electroporated into competent cells (ElectroMax DH10B, Life Technologies, Rockville, MD). Double antibiotic selection was used to isolate transformants having the genomic insert and the incorporated transposon. Plasmid DNA was extracted from single "transconjugate" colonies and sequenced using the unique primer sites present on the transposon.

In vitro transcription/translation. The TNT reaction $(50 \mu \mathrm{l})$ was performed using rabbit reticulocyte assay reagents and T3 polymerase as described by the manufacturer (Promega, Madison, WI). Two micrograms of pBS-bovine RGS9-1 (He et al., 1998) or $2 \mu \mathrm{g}$ of pBS-mouse RGS9-2 was incubated with trans- $\left({ }^{35} \mathrm{~S}\right.$ ) label (ICN Radiochemicals, Costa Mesa, CA) at $30^{\circ} \mathrm{C}$ for $2 \mathrm{hr}$. The reaction mixture was quenched with SDS sample buffer, separated by SDS-PAGE, and transferred to nitrocellulose. The blot was exposed to Kodak Biomax MR film (Kodak, Rochester, NY) for $1.5 \mathrm{hr}$.

RNA isolation and Northern blot analysis. Adult male Sprague Dawley rats (Charles River, Wilmington, DE) were exsanguinated with isotonic saline, and tissue samples were rapidly dissected, frozen on dry ice, and stored at $-80^{\circ} \mathrm{C}$ until use. Melanophore cultures were washed twice with PBS, pH 7.4, resuspended in lysis binding buffer (Ambion, Austin, TX), subjected to two spins in a refrigerated microcentrifuge (5 min, 15,000 $\mathrm{rpm}, 4^{\circ} \mathrm{C}$ ) to remove the dense melanin granules, frozen on dry ice, and stored at $-80^{\circ} \mathrm{C}$ until use. Whole RNA was isolated using the RNAqueos kit (Ambion) and quantified by spectrophotometry. For Northern blotting (Alvaro et al., 1996), RNA was electrophoresed on a $2 \%$ formaldehyde/ $1.2 \%$ agarose gel, transferred overnight to nitrocellulose by capillary action, immobilized by UV fixation, and prehybridized for $1 \mathrm{hr}$ at $65^{\circ} \mathrm{C}$ in buffer containing $20 \mathrm{~mm}$ Tris- $\mathrm{HCl}, \mathrm{pH} 7.5,0.1 \%$ sodium pyrophosphate, $0.1 \%$ SDS, $0.2 \%$ polyvinyl pyrrolidone, $0.2 \%$ Ficoll, $5 \mathrm{~mm}$ EDTA, $10 \%$ dextran sulfate, $4 \times$ SSC, $50 \%$ deionized formamide, and $100 \mu \mathrm{g} / \mathrm{ml}$ sheared and denatured salmon sperm DNA. Subsequently, ${ }^{32} \mathrm{P}$-labeled riboprobe was added at a concentration of $2 \times 10^{6} \mathrm{cpm} / \mathrm{ml}$ and hybridized overnight. The RGS9-1- and RGS9-2-specific riboprobes were complementary to the unique $3^{\prime}$ UTRs (untranslated regions) of these clones (bases 1601-2298 and 1987-2460 of murine RGS9-1 and RGS9-2, respectively). The RGS9-1 fragment was subcloned into the Srf1 site of PCRscript AMP SK(+) (Stratagene) and linearized for antisense transcription with PstI. The RGS9-2 template was generated by digesting the full-length cDNA clone in pBluescript $\mathrm{SK}^{+}$with $P v u \mathrm{II}$. The multiple tissue human blot that was used was purchased from Clontech (Palo Alto, CA). The $\mathrm{G} \alpha_{\mathrm{t}}$-specific riboprobe was complementary to bases $20-579$ of bovine $\mathrm{G} \alpha_{\mathrm{t}}$. The template was created by PCR amplification from the bovine $\mathrm{G} \alpha_{\mathrm{i}} / \mathrm{G} \alpha_{\mathrm{t}}$ chimera Chi6 [Skiba et al. (1996), and generously provided by Paul Sigler, Yale University] with the T7 RNA polymerase recognition sequence appended to the $3^{\prime}$ primer.

Western blot analysis. Dissected rat tissues (retinal protein preparation; see below) were sonicated in the presence of $8 \mathrm{M}$ urea, $100 \mathrm{~mm} \mathrm{NaH} \mathrm{PO}_{4}$, and $10 \mathrm{~mm}$ tris- $\mathrm{HCl}, \mathrm{pH} 6.3$, to solubilize total protein. Samples were centrifuged at $\sim 85,000 \times g$ for $30 \mathrm{~min}$, and protein concentration was determined by Bradford assay, using BSA as a standard. Protein $(100 \mu \mathrm{g})$ for each brain sample was $10 \%$ TCA-precipitated and redissolved with electrophoresis sample buffer. Rat retinas were dissected and solubilized in $1 \%$ SDS and then centrifuged for $30 \mathrm{~min}$ at $\sim 85,000 \times g$. Total rat retinal protein was quantitated using a BCA protein assay kit (Pierce, Rockford, IL) with BSA as a standard. Western blot analysis was performed using standard techniques (Harlow and Lane, 1998). Nitrocellulose blots were blocked with 5\% nonfat dry milk/TBS for $45 \mathrm{~min}$, followed by overnight incubation with a mouse monoclonal anti-RGS9 antibody (Cowan et al., 1998) at 1:500 dilution in $0.5 \%$ nonfat dry milk/TBS. Goat anti-mouse-HRP (Promega) was diluted 1:2000 in 0.5\% nonfat dry milk/TBS for $45 \mathrm{~min}$. Washing was performed in TBS-T (0.1\% Tween-20). Blots were developed by ECL kit (Amersham) and exposed to Kodak Biomax MR film (Kodak).

In situ hybridization. In situ hybridization was performed on freefloating sections as described by Gall et al. (1995). Briefly, male Sprague Dawley rats (250 gm; Charles River) were perfused with $4 \%$ paraformaldehyde in $0.1 \mathrm{M}$ sodium phosphate buffer (4\% PPB), and the brains were removed from the skull, post-fixed overnight in $4 \%$ PPB, and cryoprotected in $20 \%$ sucrose in PPB. Brains were sectioned at either 30 $\mu \mathrm{m}$ (coronally) or $35 \mu \mathrm{m}$ (parasagittally) on a freezing, sliding microtome into $4 \% \mathrm{PPB}$ and stored at $4{ }^{\circ} \mathrm{C}$. On the day of hybridization, sections were permeablized with proteinase $\mathrm{K}\left(1 \mu \mathrm{g} / \mathrm{ml}, 1 \mathrm{hr}, 37^{\circ} \mathrm{C}\right)$, treated with acetic anhydride $(0.25 \%$ in $0.1 \mathrm{~m}$ triethanolamine, $\mathrm{pH} 8.0)$, and then 
A

GGCACGAGGGGCCCTGCGCGCTCCGCTCTCTGTGCCTCCCGGTCTACGCCCAGGCTGGGGCAGACCAGGCTGGCTTGTGAACTTGGGGGTTTCCCCTTC 100 GCTCCCAT TCGTGT TGTGGTCGTGAAT TCATCCAGGGTCCAGAATGACGA TCCGACACCAAGGCCAGCAGTACAGGCCGAGGATGGCATT TCTCCAAAAG 200

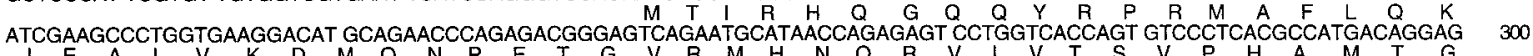

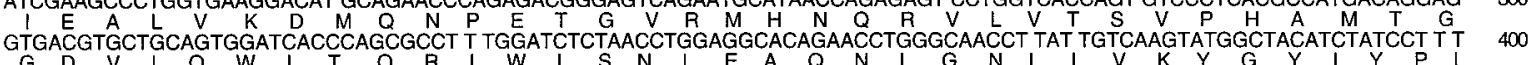

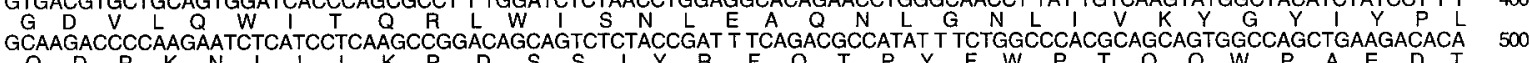

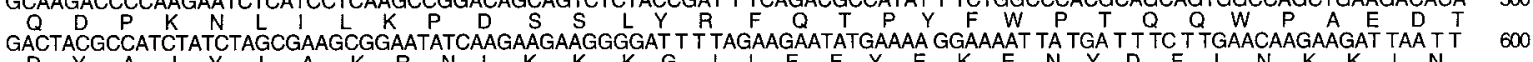

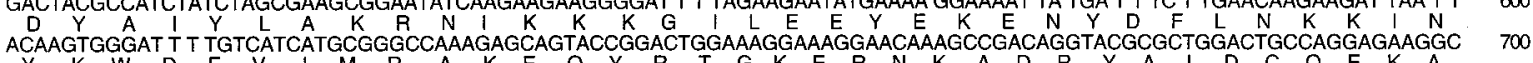

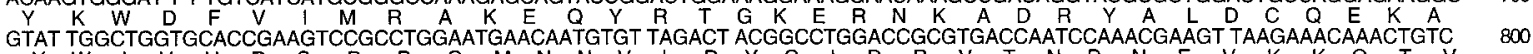

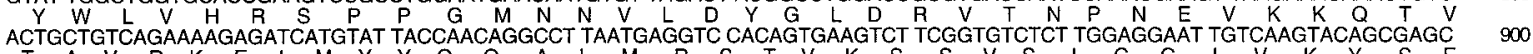

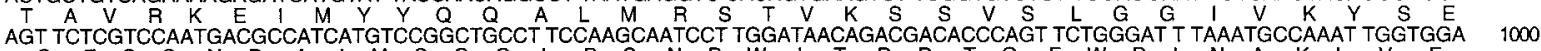
GATCCCAACCAAGATGCGAGTGGAGAGATGGGCT TCAACTCAGCGAACTGAT TCGAGACCCCAAGGGTCGGCAGAGCTCCAGTACT TCETCAAGAAG 1100

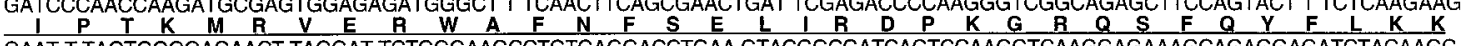

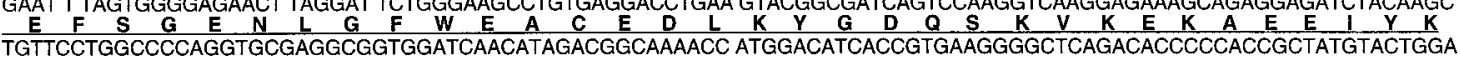

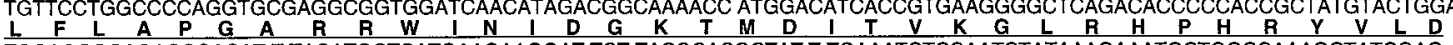

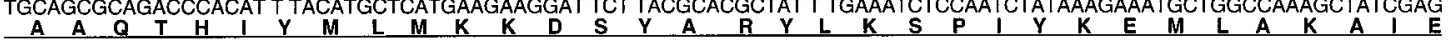

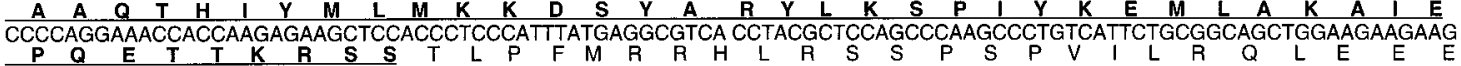

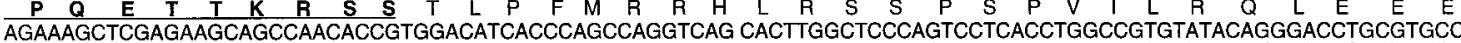

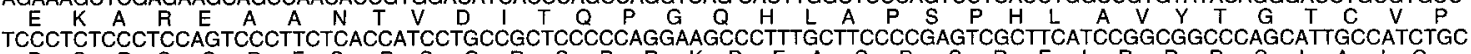

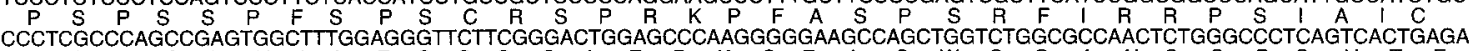

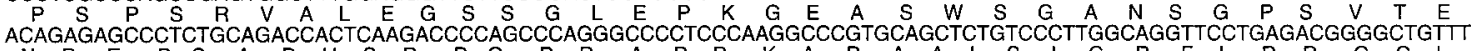
N R E P S A D H S R P Q P R A P P K A R A A L S l G R F L R R G C L

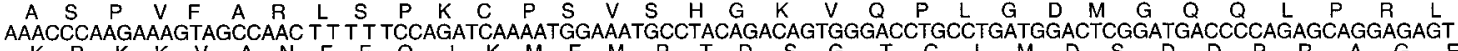
CTGGTGACCAGACCACAGAAAAAGAAGTCATCTGCCCCTGGGAGAGCCTGGCGGAAGGGAAGGCGGGCTGAGCAGGGCCITGGGCCGGGAAGATGGTCCT

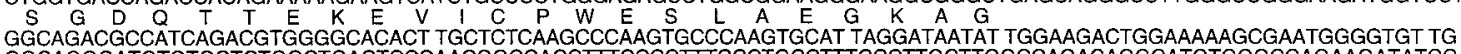
GGCAGGGATGTGTGCTCTGGCTGACTCCCAACGGCCACCTITCCCCTITCCCTGCCTTTCCCTTGCTTGGCCAGACAGGCATGTGGGCCAGAAGATATCC CTTGCTGCCTTAAAAACAATAAAAGGGTCACCTGGAGAAATTAAAAAAAAAAAAAAAAAAA

B

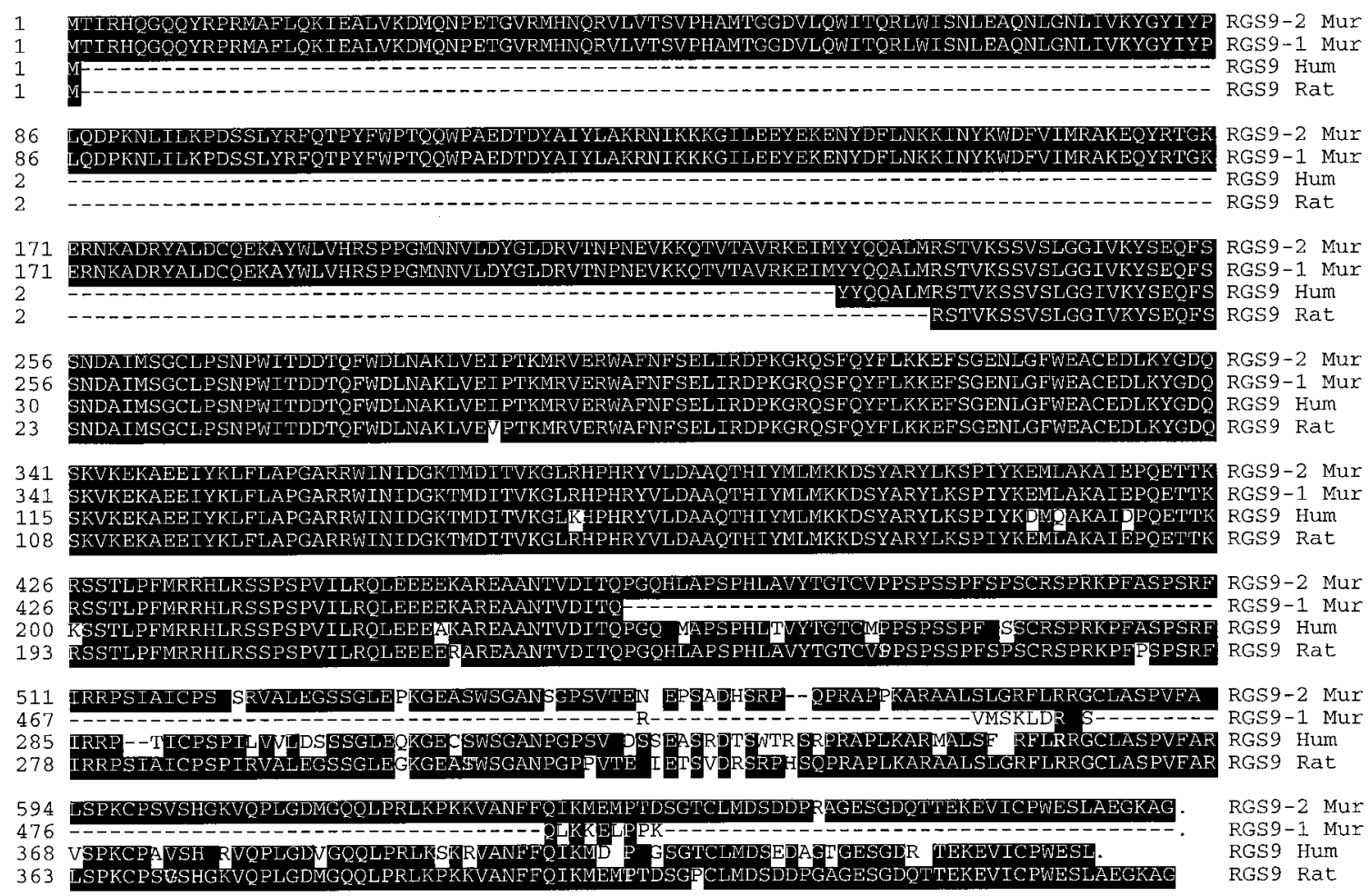

Figure 1. Cloning of full-length RGS9-2 cDNA. A, Full-length nucleotide sequence of the cDNA for RGS9-2 and conceptual translation. An open reading frame of 675 amino acids is present; the putative RGS domain is in bold and underlined, and the polyadenylation signal (AATAAA) is underlined. $B$, the predicted protein sequence for murine RGS9-2 is compared with that of human RGS9, rat RGS9, and murine RGS9-1. Conserved amino acids are depicted in solid blocks (Homo sapiens RGS9 sequence GenBank accession number AF073710). 
A

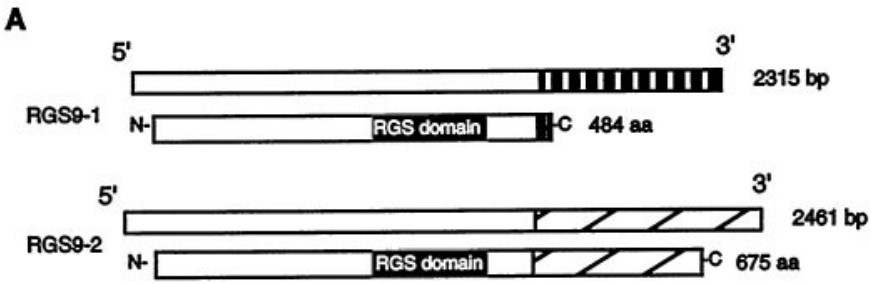

B

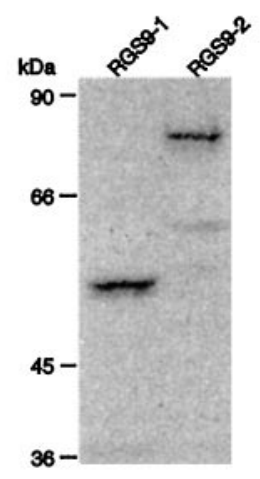

Figure 2. Comparison of RGS9-1 and RGS9-2. A, Schematized comparisons of murine RGS9-1 and RGS9-2 sequences at the nucleotide and predicted amino acid levels. The unique $3^{\prime}$ ends and carboxy ends are highlighted by vertical stripes and diagonal stripes for RGS9-1 and RGS9-2, respectively. $B$, Autoradiograph of in vitro transcription/translation products using RGS9-1 cDNA or RGS9-2 cDNA. Both RGS9 isoforms migrate at their predicted $M_{\mathrm{r}}$ (RGS9-1: $56.7 \mathrm{kDa}$; RGS9-2: $\left.76.9 \mathrm{kDa}\right)$.

hybridized overnight at $60^{\circ} \mathrm{C}$. After hybridization, sections were treated with RNase A $\left(20 \mu \mathrm{g} / \mathrm{ml}, 30 \mathrm{~min}, 37^{\circ} \mathrm{C}\right)$, washed to a stringency of $0.1 \times$ SSC, mounted onto Probe On microscope slides (Fisher, Pittsburgh, PA), and exposed to $\beta$-max Hyperfilm (Amersham). After film autoradiography, selected slides were defatted in chloroform, dipped into NTB2 nuclear emulsion (Kodak), exposed for 4-6 weeks, developed with D19 (Kodak), fixed, counterstained with cresyl violet, and coverslipped with Permount.

Immunohistochemistry. Adult male Sprague Dawley rats $(n=2)$ were perfused with isotonic saline $(100 \mathrm{ml})$ followed by $1 \%$ PPB containing $0.5 \%$ sulfosalycylic acid $(500 \mathrm{ml})$. Brains were fixed in situ for $1 \mathrm{hr}$, removed from the skull, post-fixed in perfusate for $2 \mathrm{hr}$, cryoprotected overnight in $0.1 \mathrm{M}$ sodium phosphate buffer containing $20 \%$ sucrose, cut on a freezing, sliding microtome at $40 \mu \mathrm{m}$ through coronal planes of nucleus accumbens, globus pallidus, substantia nigra, and cerebellum, blocked for $1 \mathrm{hr}$ in blocking buffer containing $0.1 \mathrm{M}$ TBS, $10 \%$ normal horse serum, $0.5 \%$ Triton X-100, and $0.5 \%$ BSA, and then incubated overnight at room temperature in blocking buffer containing anti-RGS9 monoclonal antibody at a 1:25 dilution (Cowan et al., 1998). Sections were washed three times (15 min), incubated for $1 \mathrm{hr}$ in blocking buffer containing biotinylated rat-adsorbed horse anti-mouse IgG (1:500; Vector Labs, Burlingame, CA), washed three times (15 min), incubated for $1 \mathrm{hr}$ in avidin-biotin-HRP complex (Elite kit, Vector), washed three times $(15 \mathrm{~min})$, reacted with DAB $(0.03 \%)$ and $\mathrm{H}_{2} \mathrm{O}_{2}(0.009 \%)$ in TBS for 2 min, mounted onto Probe On slides (Fisher), and coverslipped with D.P.X. (Aldrich, Milwaukee, WI). To assess the specificity of labeling, parallel series of sections were incubated in (1) blocking buffer minus primary antibody and (2) primary antibody solution preadsorbed with a tenfold excess of full-length histidine-tagged recombinant RGS9-1 (He et al., 1998). Neither control showed specific labeling.

In vitro functional studies. Xenopus laevis fibroblasts and melanophores were isolated and propagated as described previously (Daniolos et al., 1990). Pigment translocation assays were performed according to published procedures (Potenza and Lerner, 1992) in serum-free 70\% L-15 media (Life Technologies, St. Louis, MO) to minimize potential exposure of the cells to bioactive moieties from fetal calf serum (Life Technologies) during the assays. Melanophores stably expressing a human $\beta 2$ adrenergic receptor and the endogenous melatonin receptor were used [cell line described in Potenza et al. (1992)], because these cells propa- gate and transfect more efficiently than the wild-type line (A. RobyShemkovitz and M. R. Lerner, personal communication). All functional assays were performed in 96-well microtiter plates (Falcon, Franklin Lakes, NJ) by measuring transmission of light at $620 \mathrm{~nm}$ using a 340 ATTC microtiter plate reader (SLT/Tecan, Hillsborough, NC) and by using the agglutination mode of the SOFT 2000 program (SLT/Tecan). Quantification of pigment aggregation was accomplished as described previously: the formula $\Delta\left(A_{\mathrm{F}} / A_{\mathrm{I}}-1\right)$ was used to quantitate pigment aggregation in which $A_{\mathrm{I}}$ represents the initial absorbance of light at 620 $\mathrm{nm}$ by the cells and $A_{\mathrm{F}}$ is that at selected times after drug administration (Potenza et al., 1994).

Plasmid DNA constructs were created using standard molecular techniques (Sambrook et al., 1989). The murine $\mu$-opioid receptor ( $\mu \mathrm{OR}$ ) was subcloned into the eukaryotic expression vector pJG3.6 (Graminski et al., 1993) under the transcriptional regulation of the CMV promoter as described previously (Huang, 1996) to create the plasmid pJG $\mu \mathrm{OR}$. RGS-encoding plasmids, containing cDNA copies of RGS9-1 (bovine) and RGS9-2 (mouse) in forward (pJGRGS9-1F and pJGRGS9-2F, respectively) and reverse (pJGRGS9-1R and pJGRGS9-2R, respectively) orientations, were constructed. Bovine and murine RGS9-1 share $92 \%$ amino acid identity (He et al., 1998). The identities of all constructs were verified by restriction enzyme digest analysis using enzymes purchased from Boehringer Mannheim or New England Biolabs (Beverly, MA).

Plasmid DNA was transfected into the melanophores by electroporation (Potter et al., 1984; Potter, 1988) using an Electro Cell Manipulator 600 (BTX, San Diego, CA), at settings of $275 \mu \mathrm{F}, 475 \mathrm{~V}$, and R10 as described elsewhere (Potenza et al., 1992; Graminski et al., 1993). Twenty micrograms of plasmid DNA were used per electroporation with $4 \mu \mathrm{g}$ of $\mu \mathrm{OR}$-encoding plasmid, $4 \mu \mathrm{g}$ of RGS9-encoding plasmid, and the remainder LacZ-encoding plasmid. Comparable levels of RGS9-1 and RGS9-2 mRNA expression were confirmed from parallel dishes of cultures by Northern blot analysis with the pan-RGS9 riboprobe. Cells were assayed $3 \mathrm{~d}$ after electroporation. Transfection efficiency was routinely assayed by in situ staining for $\beta$-galactosidase activity of cells transfected with a LacZ-encoding plasmid as described previously (Lim and Chae, 1989; Potenza and Lerner, 1991). Rates of transfection efficiency, which did not differ significantly among the samples on given days, were routinely $30-60 \%$.

\section{RESULTS}

\section{Cloning of striatal RGS9 cDNA}

Screening of a murine forebrain cDNA library, using the RGS domain of RGS9 as a probe, yielded several overlapping clones. These clones represented a full-length cDNA of $2.5 \mathrm{~kb}$, a size similar to the striatal-enriched transcript observed on a rat multiple tissue Northern blot (Gold et al., 1997). In situ hybridization patterns produced by cRNA probes transcribed using the $3^{\prime}$ end of the isolated cDNA produced striatal-enriched patterns (see below) identical to those observed previously using the RGS domain of RGS9 (Gold et al., 1997). This strongly suggested that the full-length cDNA clone isolated here represents the striatalenriched transcript of RGS9. To differentiate between the two transcripts of RGS9, we now refer to the retinal-enriched transcript as RGS9-1 (He et al., 1998) and the striatal-enriched transcript as RGS9-2.

\section{Primary structure of RGS9-2}

Sequencing of the RGS9-2 cDNA revealed a 2461 bp insert. The full-length cDNA had in-frame stop codons upstream of the start methionine and an open reading frame of 675 amino acids. Figure $1 A$ shows the nucleotide sequence as well as the amino acid sequence of RGS9-2. The amino terminal half of the predicted protein (amino acids 30-105) contains a region that is homologous to a pleckstrin putative G-protein interacting domain. Amino acids 222-274 constitute a region that shows homology to a G-protein $\gamma$-like domain. The RGS domain in RGS9-2 spans amino acids 286-428. The deduced protein sequence of RGS9-2 contains several potential phosphorylation sites for protein kinase $\mathrm{C}$, protein kinase $\mathrm{A}$, protein kinase $\mathrm{G}$, tyrosine kinases, and 

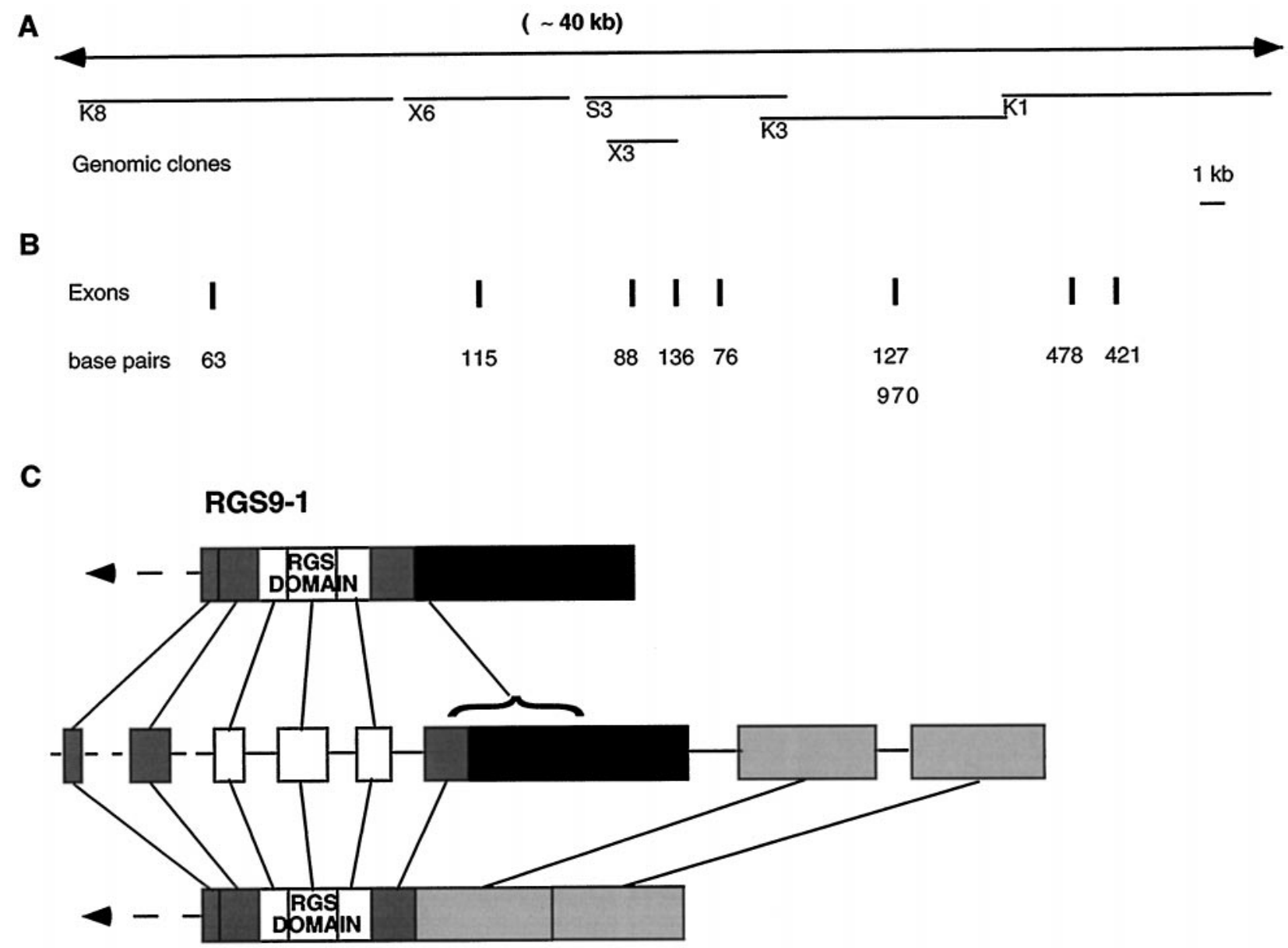

RGS9-2

Figure 3. Organization of the $3^{\prime}$ end of the mouse RGS9 gene. $A$, Genomic clones, spanning $\sim 40 \mathrm{~kb}$, subcloned into the pZero vector from a BAC. $B$, Genomic characterization of exons corresponding to the $3^{\prime}$ end of the RGS9 gene; the number of base pairs of each exon is indicated. The third exon from the $3^{\prime}$ end exists as either 970 bp in RGS9-1 or 127 bp in RGS9-2. $C$, Alternative splicing gives rise to RGS9-1 and RGS9-2; the alternatively spliced exon is shaded differentially. In addition, RGS9-2 contains two unique exons at the $3^{\prime}$ end. The shared RGS domain and the three exons that encode it are also indicated.

casein kinase II. The sequence of RGS9-2 also includes the RGS-N domain, which is conserved among Egl-10, RGS9-1, RGS6, RGS7, RGS11, and Drosophila RGS7. It is interesting to note that this RGS-N domain was missing in the two previously deposited brain RGS9 cDNAs from rat and human [Thomas et al. (1998); Homo sapiens RGS9 sequence GenBank accession number AF073710].

Figures $1 B$ and $2 A$ illustrate the similarities and differences between the cDNA sequences for RGS9-1 and RGS9-2. The predicted protein for RGS9-2 has a calculated molecular mass of $76.9 \mathrm{kDa}$. The RGS9-1 sequence predicts a protein of 484 amino acids and a calculated molecular mass of $56.7 \mathrm{kDa}$. RGS9-1 and RGS9-2 protein sequences are identical at their amino terminus through amino acid 466, after which the two protein sequences are completely divergent. The last 18 amino acids of RGS9-1 are unique when compared with RGS9-2, whereas the last 209 amino acids of RGS9-2 are unique (Fig. $2 A$ ). The $3^{\prime}$ UTRs of the two transcripts are also distinct from each other. Comparison of the cDNA sequences of RGS9-1 and RGS9-2 and of the primary structures of their respective proteins suggests that they are alternately spliced variants of the same gene. To verify the size of the two gene products, we used an in vitro transcription transla- tion reticulocyte assay system. As shown in Figure 2B, RGS9-1 and RGS9-2 yielded single, different-sized bands that corresponded well with the estimated masses of the proteins.

In Figure $1 B$, the protein sequence of RGS9-2 (murine) is compared with those for RGS9-1 (murine) and with the previously reported rat and human sequences for RGS9. The reported human RGS9 sequence is similar to murine RGS9-2 but lacks the 5' end. Similarly, a rat sequence for RGS9 described recently (Thomas et al., 1998) lacks the 5' end that is included in murine RGS9-2. Comparison of the predicted full-length amino acid sequence of RGS9-2 with the GenBank data base revealed significant homology with several members of the RGS family.

\section{Genomic characterization of RGS9}

A BAC containing a murine genomic clone that contains the RGS domain of RGS9 was obtained as described in Materials and Methods. Smaller fragments of the genomic clone were shotgunsubcloned using several restriction endonucleases and sequenced. Several of the subcloned fragments overlapped with others, and $\sim 40 \mathrm{~kb}$ of the RGS9 genomic sequence was obtained on alignment of their sequences (Fig. $3 A$ ).

The cDNA sequences of RGS9-1 and RGS9-2 were aligned to 
the genomic sequence, and their intron-exon boundaries were determined (Fig. 3B). The GT/AG consensus sequence for splice donor-acceptor sites (Padgett et al., 1986) was present at every deduced splicing junction. The intron-exon map of the RGS9 gene reveals a complex genomic organization. The genomic region sequenced to date corresponds to the 3' end of the RGS9-2 and RGS9-1 cDNAs and includes the exons corresponding to the RGS domain. To date, eight exons have been identified, which account for $61.1 \%$ of the cDNA sequence for RGS9-2 and $62.5 \%$ of that for RGS9-1. The sizes of the exons mapped range from 63 to $970 \mathrm{bp}$, and some of the intronic regions span as much as $10 \mathrm{~kb}$.

This intron-exon analysis of the RGS9 gene revealed the region that gives rise to RGS9-2 and RGS9-1 via alternative splicing. This is illustrated in Figure $3 C$, which shows that RGS9-2 contains only a portion of the $3^{\prime}$-most exon of RGS9-1, indicating that this exon is selectively spliced in RGS9-2. The remainder of this exon includes a stop codon, which accounts for the truncated sequence of RGS9-1. RGS9-2 also contains two additional exons unique to this isoform. In addition, Figure 3 shows that the RGS domain of the RGS9 isoforms, which is highly conserved among all known RGS members, is encoded by three exons.

\section{Tissue distribution of RGS9-2 and RGS9-1}

The expression patterns of the RGS9-1 and RGS9-2 splice forms were compared by Northern blots (Fig. 4A) and in situ hybridization (Fig. 5) in rat tissues. The mRNA distributions were determined using riboprobes specific to their unique 3' UTRs. To assess the degree to which the observed patterns account for all RGS9 mRNA expression in a given region, the RGS domain of RGS9 was used as a pan-RGS9 riboprobe (Fig. 4A,B). As can be seen in Figure $4 A$, RGS9 mRNA expression was observed only in retina and brain, and within the brain, high mRNA levels were seen only in striatum. RGS9-1 was highly enriched in retina, with no detectable expression in striatum. Conversely, RGS9-2 was highly enriched in striatum, with no detectable expression in retina. Hybridization to the pan probe could largely be accounted for by the combination of RGS9-1 and RGS9-2 hybridization. Thus, the principal $8.5 \mathrm{~kb}$ and $2.5 \mathrm{~kb}$ bands in retina and striatum seen with the pan probe, respectively, were also present with the RGS9-1- and RGS9-2-specific probes. In addition to the two principal bands in retina and striatum, there was evidence for additional splicing, including $\sim 1.7$ and $9.1 \mathrm{~kb}$ bands present in striatum. A similar regional distribution of RGS9 was seen in human brain, with RGS9 mRNA highly enriched in the striatum (Fig. 4B).

In situ hybridization analysis of RGS9-2 and RGS9-1 mRNA in rat brain corroborated the Northern blot data. Expression of RGS9-2 mRNA was by far most enriched in striatal regions with much less, but still significant, expression in deep layers of neocortex, dentate gyrus granule cell layer, medial amygdala, and several medial hypothalamic nuclei (Fig. 5A-F). Analysis of emulsion autoradiograms indicated that the RGS9-2 cRNA labeled the majority of large, Nissl-pale cells in striatum, suggestive of expression by most medium spiny projection neurons (Fig. $5 G$ ). Consistent with the Northern blots, mRNA encoding the RGS9-1 splice form was not detectable in brain (Fig. 5).

Finally, as can be seen in Figure 6, immunohistochemical (Fig. $6 A-F$ ) and Western blot (Fig. 6G) analysis of RGS9 protein distribution in rat using a monoclonal antibody shows that RGS9like immunoreactivity is most abundant in striatal cell body fields of nucleus accumbens, caudoputamen, and olfactory tubercle, yet absent in striatal efferents of globus pallidus and substantia nigra
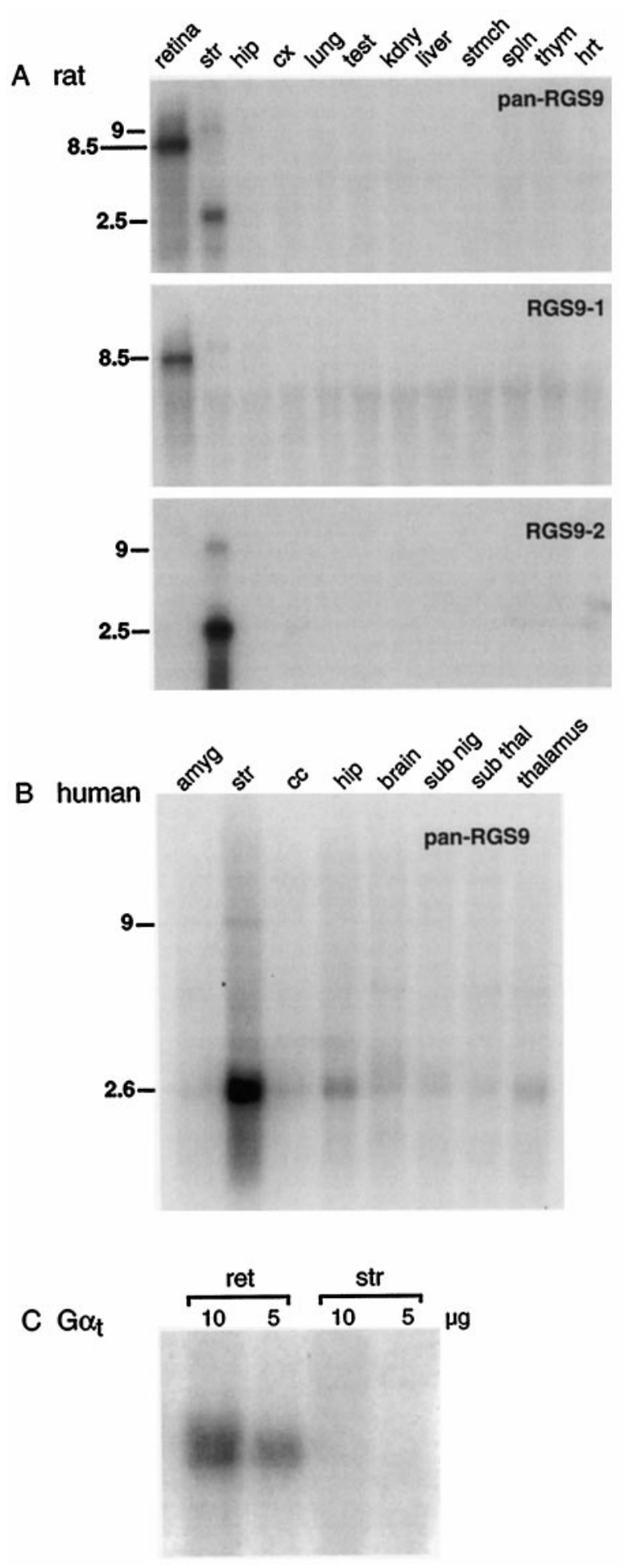

Figure 4. Tissue-specific and nonoverlapping expression of RGS9-1 and RGS9-2. $A$, Northern blot analysis of whole RNA (10 $\mu \mathrm{g})$ from multiple tissues of rat using riboprobes complementary to (1) both RGS9 splice forms (pan-RGS9), (2) RGS9-1, and (3) RGS9-2. RGS9-1 is enriched in retina, whereas RGS9-2 is enriched in striatum. $B$, Multiple brain region Northern blot of human poly $\left(\mathrm{A}^{+}\right)$RNA $(2 \mu \mathrm{g})$ using the pan-RGS9 probe illustrating the enrichment of RGS9 mRNA in human striatum. str, Striatum; hip, hippocampus; $c x$, neocortex; test, testes; kdny, kidney; stmch, stomach; spln, spleen; thym, thymus; hrt, heart; amyg, amygdala; $c c$, corpus callosum; sub nig, substantia nigra; sub thal, subthalamus. C, Levels of transducin $\left(\mathrm{G} \alpha_{\mathrm{t}}\right)$ mRNA in the striatum (str) and retina (ret) were determined by Northern blot analysis of $5-10 \mu \mathrm{g}$ of total RNA as described. 

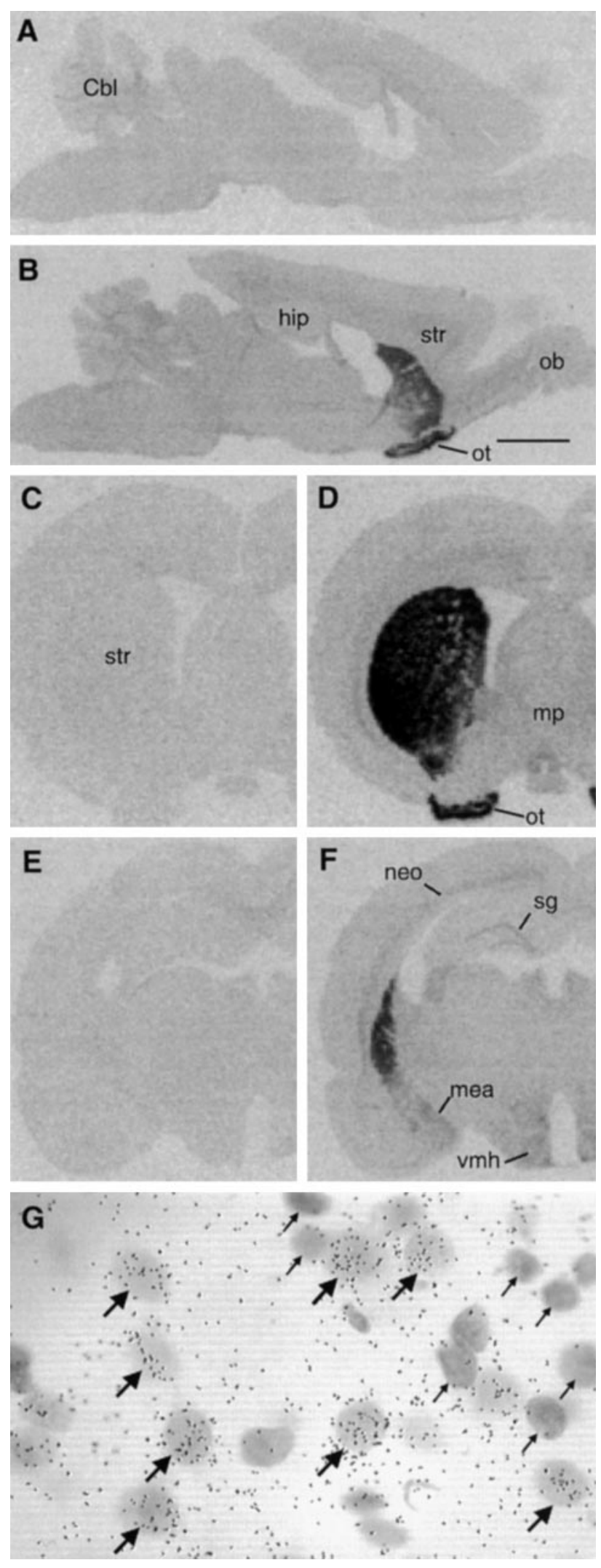

Figure 5. Tissue-specific expression of RGS9-2. Film autoradiograms $(A-F)$ of in situ hybridization using riboprobes specific for RGS9-1 and RGS9-2 in parasagittal planes $(A, B)$ and coronal planes through striatum $($ str $C, D)$ and hippocampus (hip; $E, F)$. Note that RGS9-1 cRNA labeling is not detected, whereas RGS9-2 cRNA labeling is most dense in striatum pars reticulata. In striatum, RGS9-like immunoreactivity was neuropil-like, with no apparent cell body staining. Immunostaining seen in the optic chiasm and interstitial nuclei of the medial longitudinal fasciculus may be attributed to cross-reactivity with other proteins sharing similar epitopes. In Figure $6 G$, Western blot analysis of RGS9 protein distribution in rat agrees with that observed for the mRNAs (Fig. 4). Thus, RGS9-1 protein is abundant in retina and not detectable in brain, whereas RGS9-2 protein is enriched in striatum but absent from retina. Finally, the immunoreactive bands in the striatum and the RGS9-2 reticulocyte product corroborate the predicted molecular weight of $76.9 \mathrm{kDa}$.

\section{RGS9-2 attenuates $\mu$-opioid responses in vitro}

Given the recent reports that RGS9-1 functions as a GAP for transducin (Cowan et al., 1998; He et al., 1998), it was of interest to determine whether transducin also might be enriched in striatum along with RGS9-2. Using a $\mathrm{G} \alpha_{\mathrm{t}}$-specific probe, transducin mRNA levels were assessed in the retina and in striatum by Northern analysis. High levels of $\mathrm{G} \alpha_{\mathrm{t}}$ were detected in the retina, whereas no appreciable signal was observed in striatum (Fig. 4C). This lack of $\mathrm{G} \alpha_{\mathrm{t}}$ expression in striatum suggests that the high levels of RGS9-2 in striatal projection neurons must serve as a GAP for some other $\mathrm{G} \alpha$ subunits.

To begin to study the functional effects of the striatal and retinal forms of RGS9 on G-protein-coupled receptor signaling, we used a high-throughput melanophore-based assay (Potenza et al., 1994). Melanophores were transiently transfected with the $\mu$-opioid receptor, a $\mathrm{G}_{\mathrm{i} / \mathrm{o}}$-coupled receptor prevalent in striatum, alone and in combination with RGS9-1 or RGS9-2. Cells transiently transfected with the DNA constructs in reverse orientation or with LacZ alone served as controls. Cells were tested over time for their responses to various concentrations of morphine (Fig. 7). The value $\Delta\left(A_{\mathrm{F}} / A_{\mathrm{I}}-1\right)$ is a measure of pigment aggregation and is used to assess the magnitude of the receptor $\mathrm{G} \alpha_{\mathrm{i} / \mathrm{o}}$-coupled responses to a ligand, with greater negative deflections along the $y$-axis corresponding to stronger responses (Potenza et al., 1994). Time course analyses over $2 \mathrm{hr}$ demonstrated that cells transfected with the RGS-encoding plasmids retained their abilities to aggregate pigment in response to morphine. However, RGS9-2expressing melanophores displayed a significantly diminished sensitivity to morphine (Fig. 7A). This was seen quantitatively in a twofold higher $\mathrm{EC}_{50}$ value for morphine in cells expressing RGS9-2 (30.1 $\pm 9.1 \mathrm{nM})$ compared with cells transfected with RGS9-2 in reverse orientation (14.6 $\pm 2.1 \mathrm{nM})$. Expression of RGS9-2 also caused a $\sim 30 \%$ reduction in $E_{\max }$ values for morphine (Table 1). In contrast, expression of RGS9-1 had no effect on $\mu$-opioid receptor responses in this melanophore assay system (Fig. 7C, Table 1). The difference in response to RGS9-2 versus RGS9-1 could not be accounted for by differences in (1) transfection efficiencies as assessed by $\beta$-galactosidase staining or percentages of cells responding to supramaximal morphine con-

\footnotetext{
$\leftarrow$

and olfactory tubercle $(o t)$, with far lower labeling densities in deep layers of neocortex (neo), dentate gyrus stratum granulosum ( $\mathrm{sg}$ ), medial amygdala (mea), and ventromedial hypothalamic nucleus $(v m h)$. $G$, Bright-field photomicrograph of emulsion autoradiograms of RGS9-2 cRNA hybridization in medial striatum. Note that dense silver grains are seen over larger Nissl-pale cells (large arrows) that are presumably neurons, with no grains associated with smaller Nissl-dark cells (small arrows) that are presumably glial cells. $\mathrm{Cbl}$, Cerebellum; thal, thalamus; $o b$, olfactory bulb. Scale bar (shown in $B$ ): $A, B, 2.3 \mathrm{~mm} ; C, D, 1.4 \mathrm{~mm} ; E, F, 1.6 \mathrm{~mm} ; G, 16 \mu \mathrm{m}$.
} 
centrations, (2) plating densities, or (3) the level of RGS9 isoform expression as assessed by Northern blot analysis.

As a further control, cells obtained from the same electroporation reactions were tested for their response to melatonin (Fig. $7 B$ ). Melatonin stimulates the $\mathrm{G} \alpha_{\mathrm{i} / \mathrm{o}}$-coupled melatonin receptor endogenous to the melanophores (Ebisawa et al., 1994) and, like morphine, induces pigment aggregation (Potenza et al., 1992). No significant difference in response to melatonin was observed between the RGS9-2-transfected melanophores and the controls (Fig. 7B). The lack of effect of RGS9-2 on melatonin responses, as opposed to $\mu$-opioid responses, could be attributed to the fact that the melatonin receptor is endogenous to the melanophores. Expression of RGS9-2 in a subset of cells may be insufficient to influence overall melatonin responses in the cultures. However, it is also conceivable that RGS proteins exert specific effects on particular G-protein receptors (Doupnik et al., 1997; Potenza and Nestler, 1998; Zeng et al., 1998).

\section{DISCUSSION}

A significant finding of the present study is that the RGS9 gene gives rise to at least two products, which we have termed RGS9-1 and RGS9-2, via alternative splicing. Each splice form displays a highly specific and nonoverlapping tissue distribution. RGS9-1 is highly enriched in retina with no expression detected in brain, whereas RGS9-2 is predominantly expressed in striatal regions with no expression observed in retina. Lower levels of RGS9-2 mRNA expression were detected in deep layers of neocortex, dentate gyrus granule cell layer, medial amygdala, and several medial hypothalamic nuclei. The expression pattern of RGS9-2 resembles that of many other striatal-enriched proteins, specifically several subtypes of dopamine receptors (Meador-Woodruff, 1994), adenylyl cyclase type V (Glatt and Snyder, 1993), DARPP-32 (Hemmings et al., 1989; Brene et al., 1994), $\mathrm{G}_{\alpha}$ olf (Herve et al., 1993), and $\mathrm{G} \gamma_{7}$ (Betty et al., 1998). Comparison of the amino acid sequences of the deduced proteins of RGS9-2 and RGS9-1 reveals that the two splice variants are identical for most of the protein and differ in their carboxy ends only. Eighteen amino acids (amino acids 466-484) present at the carboxy end of RGS9-1 are unique to this variant. Conversely, the last 209 amino acids of RGS9-2 (amino acids 466-675) are unique.

The nucleotide sequence of murine RGS9-2 appears to be similar to that of a recently reported rat (Thomas et al., 1998) and human homolog, but differs from it at the 5' end. The deduced proteins for the rat and human RGS9 clones are reported to be only 444 amino acids, far shorter than the RGS9-2 clone reported here that encodes a protein of predicted 675 amino acids. Comparison with RGS9-2 shows that the predicted protein sequence of the rat and human cDNAs represents a subset of the predicted amino acid sequence for RGS9-2. One possibility is that these clones reported previously are not full length and lack their amino terminal portion. Another possibility is that the clones represent yet a third splice form of RGS9.

Genomic characterization reveals the RGS9 gene to be complex. Sequencing of $40 \mathrm{~kb}$ of genomic DNA to date has resulted in the mapping of $60 \%$ of the cDNA sequence of RGS9-2 and RGS9-1, which is distributed across eight and six exons, respectively. The third exon from the $3^{\prime}$ end of the gene is truncated in the case of RGS9-2, which results in the striatal-enriched isoform that contains only a portion (127 bp) of the exon. In contrast, RGS9-1 contains 970 bp of this alternatively spliced exon. From the genomic sequence obtained thus far, the possibility remains that the RGS9-1 isoform arises from an early termination of
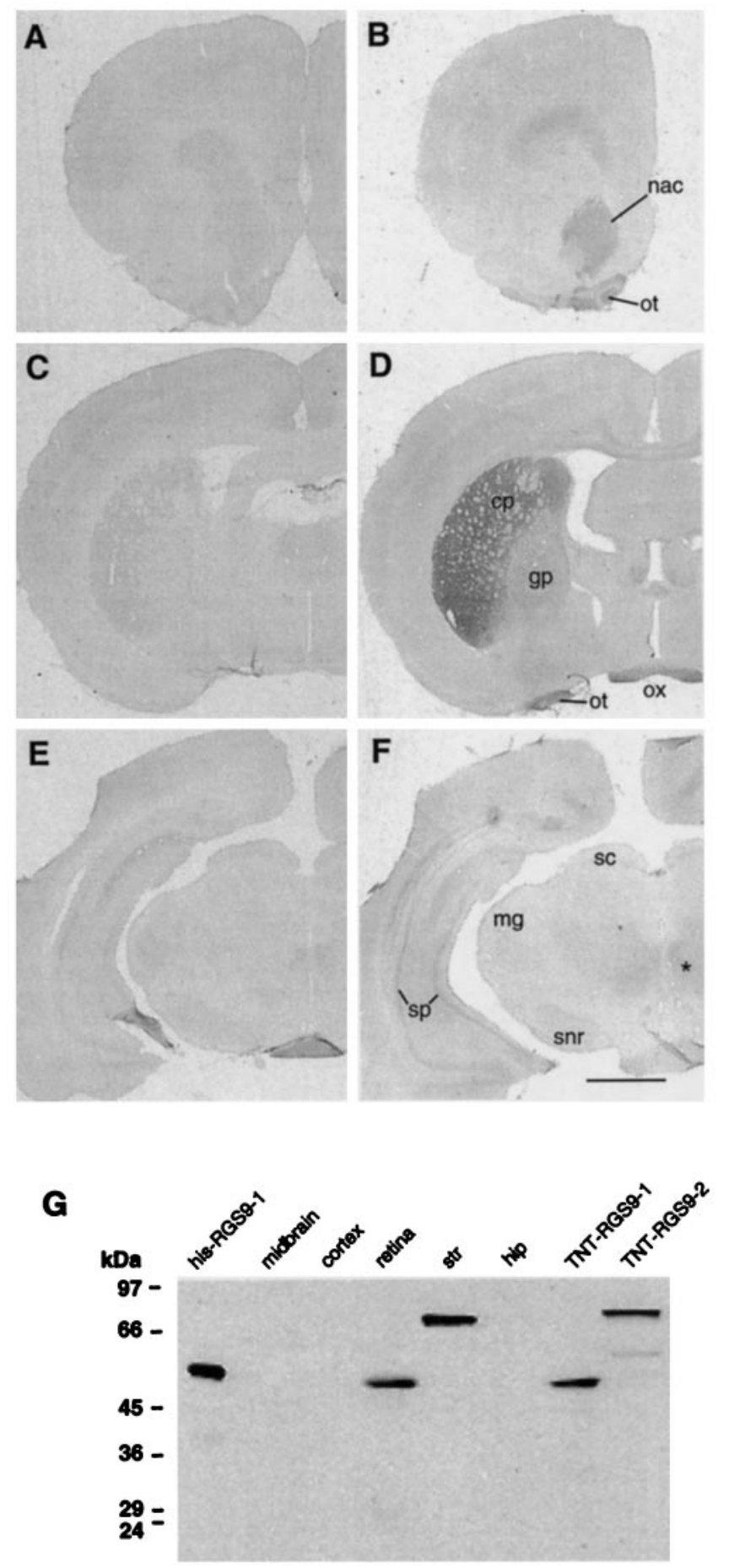

Figure 6. RGS9-like immunoreactivity localizes to cell body fields of striatum. Dense RGS9-like immunostaining using a monoclonal antibody is restricted to striatal cell body regions $(A-D)$ and is absent in terminal fields of the globus pallidus $(g p ; C, D)$ and substantia nigra pars reticulata $(s n r ; E$, $F)$. Sections in $A, C, E$ and $B, D, F$ were incubated without and with primary antibody, respectively. $c p$, Caudoputamen; $m g$, medial geniculate nucleus; nac, nucleus accumbens; ot, olfactory tubercle; ox, optic chiasm; $s c$, superior colliculus; $s p$, hippocampal stratum pyramidale. Scale bar, $1.5 \mathrm{~mm}$. $G$, Western blot analysis of RGS9-like immunoreactivity in rat nervous tissues using monoclonal anti-RGS9 antibody. Protein samples in lanes left to right include histidine tagged-RGS9-1 (his-RGS9-1) (5 ng) (He et al., 1998); midbrain $(100 \mu \mathrm{g})$; cortex $(100 \mu \mathrm{g})$; retina $(26 \mu \mathrm{g})$; striatum (str) (100 $\mu \mathrm{g})$; hippocampus (hip) (100 $\mu \mathrm{g})$; RGS9-1 translated in vitro (TNT-RGS91); and RGS9-2 translated in vitro (TNT-RGS9-2). 

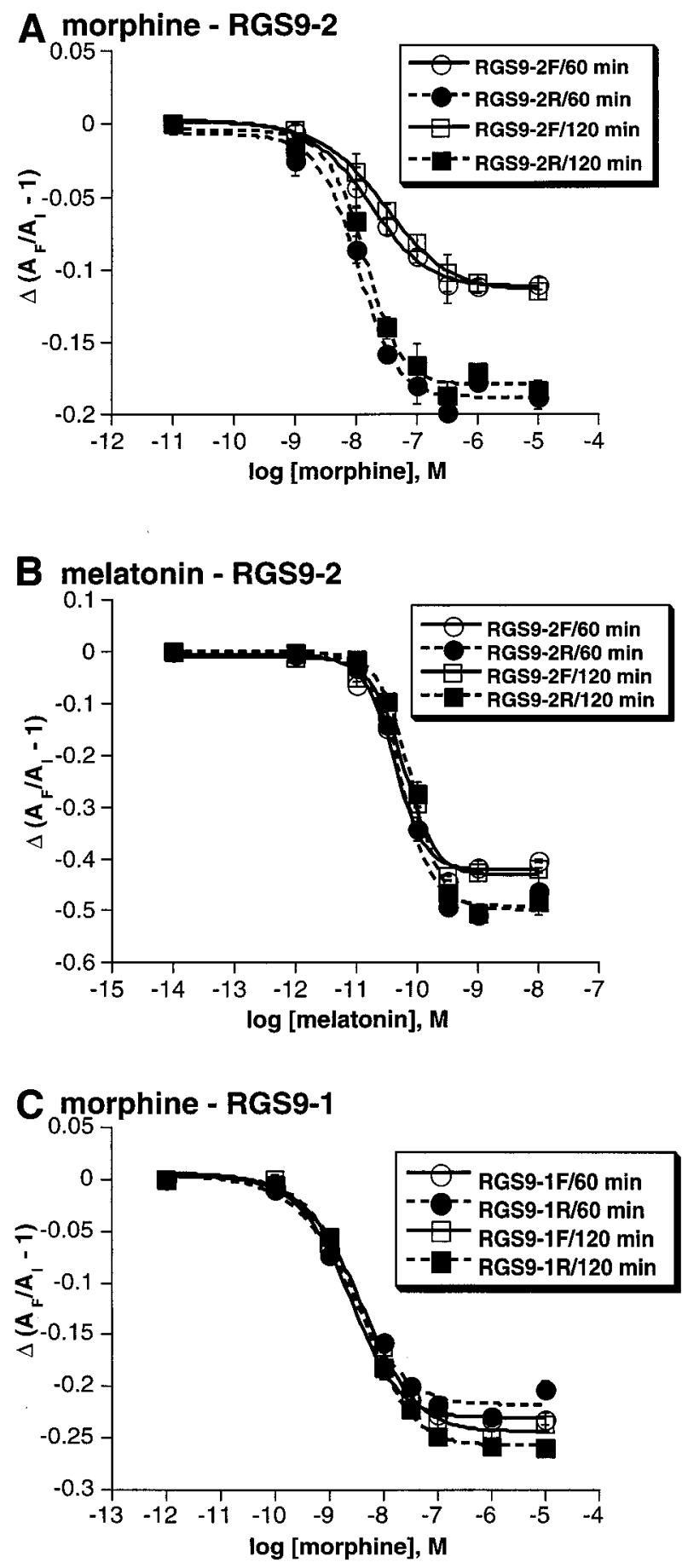

Figure 7. Responses of RGS9-transfected melanophores to morphine $(A, C)$ and melatonin $(B)$. Concentration-response curves are shown for cells transiently transfected with plasmids encoding the $\mu$-opioid receptor in combination with those encoding RGS9 in forward $(F)$ or reverse $(R)$ orientations. Cells were transfected with either RGS9-2 constructs $(A, B)$ or RGS9-1 constructs $(C)$. Note that the differences in $\mathrm{EC}_{50}$ values for morphine shown in $A$ and $C$ are not attributable to the RGS9 isoform transfected. Rather, the experiments were performed at different times, the differences were seen for melatonin as well as morphine, and $\mathrm{EC}_{50}$ values typically vary across experiments. Error bars represent SEMs for triplicate samples. Results shown are representative of duplicate experiments.
Table 1. Effect of RGS9-2 and RGS9-1 expression on $E_{\max }$ values for morphine in melanophore assays

\begin{tabular}{lll} 
& $\Delta\left(A_{\mathrm{F}} / A_{\mathrm{I}}-1\right)$ & $\begin{array}{l}\text { Forward as percentage } \\
\text { of reverse }\end{array}$ \\
\hline RGS9-2 (forward) & $-0.1695 \pm 0.0039$ & $71 \%(p<0.05)$ \\
RGS9-2 (reverse) & $-0.2380 \pm 0.0061$ & \\
RGS9-1 (forward) & $-0.2592 \pm 0.0037$ & $104 \%$ \\
RGS9-1 (reverse) & $-0.2496 \pm 0.0062$ & \\
\hline
\end{tabular}

Melanophores were transfected with the $\mu$ opioid receptor, along with RGS9-2 or RGS9-1 in the forward or reverse orientation, and pigment dispersion responses $\left[\Delta\left(A_{\mathrm{F}} / A_{\mathrm{I}}-1\right)\right]$ were calculated over time. Shown are $\Delta\left(A_{\mathrm{F}} / A_{\mathrm{I}}-1\right)$ values after 120 min of morphine exposure, when maximal responses $\left(E_{\max }\right)$ were achieved. Data are expressed as mean $\pm \operatorname{SEM}(n=3)$. Equivalent results were obtained in a second independent experiment.

transcription and not from alternative splicing. RGS9-2 also contains two additional exons unique to this isoform, resulting in an open reading frame of 675 amino acids. On the other hand, RGS9-1 has an open reading frame of only 484 amino acids because of a stop codon in the alternatively spliced exon (not present in RGS9-2). Given our earlier observation that differentsized transcripts exist in the brain for RGS9 (Gold et al., 1997), we suspect that additional splicing might be occurring, although this must await further analysis. We also have obtained additional BAC genomic clones that correspond to the 5' end of the RGS9 gene. These clones should enable the complete genomic mapping of RGS9 isoforms and analysis of the 5' promoter sequence of this gene. Interestingly, our partial mapping of the intron-exon structure of the RGS9 gene revealed that the RGS domain, which is highly conserved among all members of the RGS family, is encoded by three exons. Consistent with this finding, the RGS domain in the human RGS3 gene was similarly mapped onto three exons (Chatterjee et al., 1997), which provides support for a common ancestral mammalian RGS gene.

Analysis of the RGS9 gene could provide a better understanding of the mechanisms by which highly tissue-specific expression of protein isoforms is obtained. The RGS9 gene gives rise to at least two splice forms, each of which shows a highly restricted and nonoverlapping tissue distribution. Complete genomic characterization of the RGS9 gene should provide information concerning specific promoter sequences, as well as perhaps specific intronic sequences, that are responsible for the differential expression patterns observed. Similarly, biochemical analysis of retina and striatum could provide information concerning trans-acting factors specific to either tissue that interact with the RGS9 gene or its primary transcript to generate the specific splice forms of the protein.

Presumably, the selective expression of RGS9-1 to retina and of RGS9-2 to striatum subserves functional roles unique to these tissues. One can speculate that the existence of two splice forms may enable the expression of each to be regulated independently in the two tissues, either during development or in response to external perturbations in the adult organism or both. Another possibility, not incompatible with the first, is that the two forms of RGS9 have different functional properties that are specific to their sites of expression. Functional differences between RGS9-1 and RGS9-2 might be expected, given their unique carboxy ends. However, given our general lack of knowledge concerning the functions subserved by various domains of RGS proteins other than their RGS domain, it is unclear which functions might be different between the RGS9 isoforms. Recent biochemical studies 
of rod outer segments suggest that the C terminus of RGS9-1 may be involved in interactions with specific rod outer segment membrane proteins (W. He and T. G. Wensel, unpublished observations).

It is interesting to note in this regard that one difference between RGS9-2 and RGS9-1 could concern the subtype of G-protein $\alpha$ subunit targeted by these proteins. G-protein subunits have been shown to be differentially expressed in brain (Brann et al., 1987; Ericksson et al., 1995; Betty et al., 1998). Selective interactions between the various $\alpha, \beta$, and $\gamma$ subunits, as well as between various receptor and effector proteins, have been established in vitro (Schmidt et al., 1992; Fletcher et al., 1998). Interestingly, the distribution pattern of one particular $\gamma$ subunit $\gamma_{7}$ in rat brain (Betty et al., 1998) resembles that of RGS9-2. RGS9-1 has been shown to function as a GAP for $\mathrm{G} \alpha_{\mathrm{t}}$. In the current study we show that $\mathrm{G} \alpha_{\mathrm{t}}$ is not expressed at appreciable levels in striatum, which suggests that RGS9-2 likely interacts with a different $\mathrm{G} \alpha$ subunit in this tissue. We also show that RGS9-2, but not RGS9-1, represses the signaling efficacy of the $\mu$-opioid receptor, which is known to be $\mathrm{G}_{\mathrm{i} / \mathrm{o}}$-linked (Fleming et al., 1992). This effect of RGS9-2 is consistent with its functioning as a GAP, because activation of GTPase activity of a G-protein $\alpha$ subunit would be predicted to shorten its time of activation and thereby inhibit receptor-effector coupling via the G-protein. This finding thereby raises the possibility that RGS9-2 selectively targets $G_{i / o}$. Further work is needed to confirm this hypothesis and to determine whether the unique carboxy ends of RGS9-1 versus RGS9-2 are responsible for their selective targeting of different G-protein $\alpha$ subunits and perhaps other distinct functions.

The presence of alternatively spliced isoforms of an RGS gene and their tissue-selective expression provide a further level of complexity in G-protein-mediated signaling. In concert with tissue-specific expression of numerous interacting G-protein subunits, extraordinary specificity and fine tuning of these signaling pathways could be achieved. The protein sequence of the available human clone of RGS9 bears strong homology with RGS9-2, and recently a cDNA corresponding to RGS9-1 has been isolated from a human retinal cDNA library (W. Baehr and T. G. Wensel, unpublished observations). It will be particularly interesting to explore the roles of RGS9-1 and RGS9-2, and perhaps additional splice variants, in neuronal signaling in humans. The highly specific expression patterns of these distinct gene products argue strongly for distinct functional roles, and for the importance of their C-terminal domains in those functions.

Note added in proof. GS9-2 GenBank accession number AF125046. While this paper was in review, Granneman et al. (1998) reported the identification of a striatal-enriched RGS9 isoform from rat and human termed RGS9L that is a homolog to the murine RGS9-2 splice form reported here.

\section{REFERENCES}

Alvaro JD, Tatro JB, Quillan JM, Fogliano M, Eisenhard M, Lerner MR, Nestler EJ, Duman RS (1996) Morphine down-regulates melanocortin-4 receptor expression in brain regions that mediate opiate addiction. Mol Pharmacol 50:583-591.

Arshavsky VY, Pugh EN (1998) Lifetime regulation of G proteineffector complex: emerging importance of RGS proteins. Neuron 20:11-14.

Berman DM, Gilman AG (1998) Mammalian RGS proteins: barbarians at the gate. J Biol Chem 273:1269-1272.

Betty M, Harnish SW, Rhodes KJ, Cockett MI (1998) Distribution of heterotrimeric G-protein $\beta$ and $\gamma$ subunits in the rat brain. Neuroscience 85:475-486.

Brann MR, Collins RM, Spiegel A (1987) Localization of mRNAs en- coding the $\alpha$ subunits of signal-transducing G-proteins within rat brain and among peripheral tissues. FEBS Lett 222:191-198.

Brene S, Lindefors N, Ehrlich M, Taubes T, Horiuchi A, Kopp J, Hall H, Sedvall G, Greengard P, Persson H (1994) Expression of mRNAs encoding ARPP-16/19, ARPP-21, and DARPP-32 in human brain tissue. J Neurosci 14:985-998.

Burchett SA, Volk ML, Bannon MJ, Granneman JG (1998) Regulators of $G$ protein signaling: rapid changes in mRNA abundance in response to amphetamine. J Neurochem 70:2216-2219.

Chatterjee TK, Eapen A, Kanis AB, Fisher RA (1997) Genomic organization, 5'-flanking region and chromosomal localization of the human RGS3 gene. Genomics 45:429-433.

Cowan CW, Fariss RN, Sokal I, Palczewski K, Wensel TG (1998) High expression levels in cones of RGS9, the predominant GTPase accelerating protein of rods. Proc Natl Acad Sci USA 95:5351-5356.

Daniolos A, Lerner AB, Lerner MR (1990) Action of light on frog pigment cells in culture. Pigment Cell Res 3:38-43.

Devine SE, Boeke JD (1994) Efficient integration of artificial transposons into plasmid targets in vitro: a useful tool for DNA mapping, sequencing and functional analysis. Nucleic Acids Res 22:3765-3772.

Dohlman HG, Thorner J (1997) RGS proteins and signaling by heterotrimeric G proteins. J Biol Chem 272:3871-3874.

Doupnik CA, Davidson N, Lester HA, Kof uji P (1997) RGS proteins reconstitute the rapid gating kinetics of $\mathrm{G} \beta \gamma$-activated inwardly rectifying $\mathrm{K}^{+}$channels. Proc Natl Acad Sci USA 94:10461-10466.

Ebisawa T, Karne S, Lerner MR, Reppert SM (1994) Expression cloning of a high-affinity melatonin receptor from Xenopus dermal melanophores. Proc Natl Acad Sci USA 91:6133-6137.

Eriksson PS, Nilsson M, Matejka GL (1995) Distribution and development of G $\alpha \mathrm{i}-2$ mRNA in the rat cerebral cortex investigated with in situ hybridization and RNAase protection assay. Dev Brain Res 84:208-214.

Fleming LM, Ponjee G, Childers SR (1992) Inhibition of protein phosphorylation by opioid-inhibited adenylyl cyclase in rat brain membranes. J Pharmacol Exp Ther 260:1416-1424.

Fletcher JE, Lindorfer MA, DeFilippo JM, Yasuda H, Guilmard M, Garrison JC (1998) The G protein $\beta_{5}$ subunit interacts selectively with the $\mathrm{G}_{\mathrm{q}} \alpha$ subunit. J Biol Chem 273:636-644.

Gall C, Lauterborn J, Guthrie K (1995) In situ hybridization: a sensitive measure of activity-dependent changes in neuronal gene expression. In: Autoradiography and correlative imaging (Stumf W, Solomon HF, eds), pp 379-399. San Diego: Academic.

Glatt CF, Snyder SH (1993) Cloning and expression of an adenylyl cyclase localized to the corpus striatum. Nature 361:536-538.

Gold SJ, Ni YG, Dohlman HG, Nestler EJ (1997) Regulators of G-protein signaling (RGS) proteins: region-specific expression of nine subtypes in rat brain. J Neurosci 17:8024-8037.

Graminski GF, Jayawickreme CK, Potenza MN, Lerner MR (1993) Pigment dispersion in frog melanophores can be induced by a phorbol ester or stimulation of a recombinant receptor that activates phospholipase C. J Biol Chem 268:5957-5964.

Granneman JG, Zhai Y, Zhu Z, Bannon MJ, Burchett SA, Schmidt CJ, Andrade R, Cooper R (1998) Molecular characterization of human and rat RGS 9L, a novel splice variant enriched in dopamine target regions, and chromosomal localization of the RGS 9 gene. Mol Pharmacol 54:687-694.

Harlow H, Lane D (1998) Antibodies: a laboratory manual. Cold Spring Harbor, NY: Cold Spring Harbor Laboratories.

He W, Cowan CW, Wensel TG (1998) RGS9, a GTPase accelerator for phototransduction. Neuron 20:95-102.

Hemmings Jr HC, Nairn AC, McGuinness TL, Huganir RL, Greengard P (1989) Role of protein phosphorylation in neuronal signal transduction. FASEB J 3:1583-1592.

Herve D, Levi-Strauss M, Marey-Semper I, Verney C, Tassin JP, Glowinski J, Girault JA (1993) G(olf) and Gs in rat basal ganglia: possible involvement of $\mathrm{G}($ olf $)$ in the coupling of dopamine D1 receptor with adenylyl cyclase. J Neurosci 13:2237-2248.

Huang L (1996) Studies of G protein coupled receptors and their ligands with Xenopus laevis melanophores system. PhD thesis, Yale University.

Koelle M, Horvitz HR (1996) EGL-10 regulates G protein signaling in the $C$. elegans nervous system and shares a conserved domain with many mammalian proteins. Cell 84:115-125.

Lim K, Chae C (1989) A simple assay for DNA transfection by incuba- 
tion of the cells in culture dishes with substrates for beta-galactosidase. Biotechniques 7:576-579.

Meador-Woodruff JH (1994) Update on dopamine receptors. Ann Clin Psychiatry 6:79-90.

Padgett RA, Grabowski PJ, Konarska MM, Seiler S, Sharp PA (1986) Splicing of messenger RNA precursors. Annu Rev Biochem 55:1119-1150.

Potenza MN, Lerner MR (1991) A recombinant vaccinia virus infects Xenopus melanophores. Pigment Cell Res 4:186-192.

Potenza MN, Lerner MR (1992) A rapid quantitative bioassay for evaluating the effects of ligands upon receptors that modulate cAMP levels in a melanophore cell line. Pigment Cell Res 5:372-378.

Potenza MN, Nestler EJ (1998) Signaling via G-protein coupled receptors is differentially regulated by expression of specific RGS proteins in a melanophore-based bioassay. Soc Neurosci Abstr 24:362.

Potenza MN, Graminski GF, Lerner MR (1992) A method for evaluating the effects of ligands upon Gs protein coupled receptors using a recombinant melanophore-based bioassay. Anal Biochem 206:315-322.

Potenza MN, Graminski GF, Schmauss C, Lerner MR (1994) Functional expression and characterization of human D2 and D3 dopamine receptors. J Neurosci 14:1463-1476.

Potter H (1988) Electroporation in biology: methods, applications and instrumentation. Anal Biochem 174:361-373.

Potter H, Weir L, Leder P (1984) Enhancer-dependent expression of human $\kappa$ immunoglobulin genes introduced into mouse pre-B lymphocytes by electroporation. Proc Natl Acad Sci USA 81:7161-7165.
Saitoh O, Kubo Y, Miyatani Y, Asano T, Nakata H (1997) RGS8 accelerates G-protein-mediated modulation of $\mathrm{K}^{+}$currents. Nature 390:525-529.

Sambrook J, Fritsch EF, Maniatis T (1989) Molecular cloning: a laboratory manual. Cold Spring Harbor, NY: Cold Spring Harbor Laboratories.

Saugstad JA, Marino MJ, Folk JA, Helper JR, Conn JP (1998) RGS4 inhibits signaling by group I metabotropic glutamate receptors. J Neurosci 18:905-913.

Schmidt CJ, Thomas TC, Levine MA, Neer EJ (1992) Specificity of G protein $\beta$ and $\gamma$ subunit interactions. J Biol Chem 267:13807-13810.

Shuey DJ, Betty M, Jones PG, Khawaja XZ, Cockett MI (1998) RGS7 attenuates signal transduction through the $G_{\alpha q}$ family of heterotrimeric G proteins in mammalian cells. J Neurochem 70:1964-1972.

Skiba NP, Bae H, Hamm HE (1996) Mapping of effector binding sites of transducin $\alpha$-subunit using $\mathrm{G} \alpha_{\mathrm{t}} / \mathrm{G} \alpha_{\mathrm{i} 1}$ chimeras. J Biol Chem 271:413-424.

Thomas EA, Danielson PE, Sutcliffe JG (1998) RGS9: a regulator of G-protein signaling with specific expression in rat and mouse striatum. J Neurosci Res 52:118-124.

Zeng W, Xu X, Popov S, Mukhopadhyay S, Chidiac P, Swistok J, Danho W, Yagaloff KA, Fisher SL, Ross EM, Muallem S, Wilkie TM (1998) The N-terminal domain of RGS4 confers receptor-selective inhibition of G protein signaling. J Biol Chem 273:34687-34690.

Zerangue N, Jan LY (1998) G-protein signaling: fine-tuning signaling kinetics. Curr Biol 8:R313-316. 